applied entomologist is not enough. Existing knowledge is too inadequate. In all the fields-agricultural entomology, insect pests in stored products or in timber, the locust problem, and the rest-we need an unbroken chain of research workers at all levels from the theoretical to the practical ; and the entomologists at the most practical end must be shielded from petty incursions upon their time, so that they may get on with their proper work of investigation. For the entomologist in the Colonies there is the added need for contact with libraries and centres of research in Britain and elsewhere if the stimulus to investigation is to be maintained.

But is entomological research still necessary in the applied field ? Or is the entomologist, in fact, outmoded by the discoveries of the organic chemist in the realm of insecticides? The discovery of the insecticidal properties of DDT, 'Gammexane' and the organophosphorus compounds respectively in Switzerland, Great Britain and Germany has transformed the control of insect pests during the past ten years. But it is becoming increasingly evident that the use of more and more insecticides is creating insect problems as fast as it solves them. We can probably control any specific orchard pest, for example, with which we have to deal-but the problem of orchard pests in general gets worse. There is, in fact, increasing scope and need for entomological research-to guide intelligently, to supplement, and sometimes even to supplant the application of chemical measures of control by the more subtle and more remunerative methods of biology.

\section{THE UPLAND PLAINS OF BRITAIN : THEIR ORIGIN AND GEOGRAPHICAL SIGNIFICANCE}

$\mathrm{P}$ ROF. S. W. WOOLDRIDGE surveys some of the problems of the later stages of landscape evolution in Britain, and particularly the evidence afforded by well-marked erosion surfaces developed over a wide range of altitude, in his presidential address to Section E (Geography). Though much work has been done on these surfaces both by geologists and geographers, the evidence as a whole has not yet been faced, nor general conclusions proposed. It is clear that no adequate reconstruction of the stages of development of the British land-surface can ignore such evidence; the partial explanation frequently proposed tends to hark back to older structural episodes which are, in fact, largely irrelevant to the question.

The key area is south-east Fingland, where a widespread surface of marine planation at about $600 \mathrm{ft}$. retains traces of a cover of known (Newer Pliocene) age. Above it, the summit areas retain remnants of an earlier peneplain, while at lower elevations there are extensive remnants at about 400 and $200 \mathrm{ft}$. O.D. respectively, the former being evidently of late Pliocene or early Pleistocene age. The Bristol district exhibits remnants of upland plains at the same three altitudes and also at $750-800 \mathrm{ft}$. In east Devon the sequence of surfaces is fuller, as shown by J. F. N. Green, who distinguished six 'platforms', interpreted as marine strand-flats, between 500 and $1,000 \mathrm{ft}$. O.D. The evidence is continued farther west in Devon and Cornwall, where platforms at about 1,000, 800 and $400 \mathrm{ft}$. have long been known. The west-coast areas from Cornwall northwards to Cumberland, and parts of the Irish coast, reveal a closely similar succession of platforms, and there are indications of the occurrence of some of them in Scotland. No similar evidence is available from the east coast of England, the region having presumably suffered tilting or warping towards the North Sea depression. Over much of the rest of the country, however, there is evidence of long-continued stability, involving either uniform uplift of the land or a spasmodically sinking sea-level.

It is concluded that the major platforms up to a height of $1,000 \mathrm{ft}$. are, in general, of marine origin and not older than Pliocene in age, though the higher summit planes of the Welsh mountains, Pennines, etc., most probably represent surfaces of sub-aerial planation of earlier Tertiary date. The acceptance of these conclusions carries important implications for geophysics and stratigraphical geology, as well as geomorphology. In the latter field, they afford an outline of a coherent story of the earlier stages of coastal evolution and throw much light on the development of river systems. Further, it is manifest that if the several 'upland-plains' of Britain represent surfaces exposed for periods of differing duration to soil-forming processes, physiographical analysis is vitally relevant to the study of soil character, and therefore of considerable importance to the plant ecologist as well as to students of land utilization and land clessification.

\section{ECONOMIC PROGRESS : RETROSPECT AND PROSPECT}

TN his presidential address before Section $\mathbf{F}$ 1 (Economics and Statistics), Prof. G. C. Allen points out that statistical investigations, as well as common observation, show that a great advance in income per head took place in Great Britain in the half-century before the Second World War. Even in the years between the two World Wars, which are often mistakenly looked upon as years of stagnation, there was probably a rise of about 25 per cent in real income per head. The main cause of this improvement was the growth in industrial productivity; it has been estimated that, between 1907 and 1937 , output per man-hour grew by more than 80 per cent in real terms, and most of this increase occurred after 1924

It was this experience which led to the optimistic forecasts of our economic future that were made shortly before the end of the Second World War. Our troubles since 1945 have, however, produced a more gloomy mood, and this has been intensified by the results of various inquiries which have revealed weaknesses in our industrial capacity, especially in comparison with that of the United States. Many of these weaknesses have been attributed to our unsatisfactory or obsolete equipment, and it is commonly asserted that they can be removed only by greatly increasing investment in our undercapitalized industries. While capitalization and productivity are, of course, very closely linked, it is doubtful if the above diagnosis is entirely adequate; for our productivity is lower than that of some other countries, even in industries in which there is no wide disparity in the amount of capital used per worker. 